International institutions and domestic policy: assessing the influence of multilateral pressure on the European Union's Agricultural Policy

Patricia Garcia-Duran, professor at the_Economic History Department of the University of Barcelona

Facultat de Economia i Empresa

Av. Diagonal, 690

E-08034 Barcelona

patriciagarciaduran@ub.edu

Miriam Casanova

Professor at the_Economic History Department of the University of Barcelona

Facultat de Economia i Empresa

Av. Diagonal, 690

E-08034 Barcelona

miriamcasanova@ub.edu

Corresponding author: L. Johan Eliasson, professor at East Stroudsburg University

(jeliasson@esu.edu),

L. Johan Eliasson, Ph.D.

Professor, Department of Political Science and Economics

East Stroudsburg University

200 Prospect Street

East Stroudsburg, PA 18301

(570) 422-3250

We thank Montserrat Millet, Robert Ackrill, two JEI reviewers, and the JEI editors for their incisive comments. This article falls within the EU-NormCon research project (Normative contestation in Europe: Implications for the EU in a changing global order) funded by the National R+D Plan of the Spanish Ministry of Economy and Competiveness (CSO2016-79205-P). 


\section{International institutions and domestic policy: assessing the influence of multilateral pressure on the European Union's Agricultural Policy}

There is a debate in international relations on how, when, and why international institutions influence domestic policy. This article contributes to this debate by looking at the influence of the World Trade Organization (WTO) on the European Union's (EU) Common Agricultural Policy (CAP). It shows that the transfer of authority to international institutions may transform an external factor into a permanent influence on domestic policy. The transfer of authority in agriculture to the General Agreement on Tariffs and Trade (GATT - now included in the WTO) in 1994 led to the introduction of a dormant clause on export subsidies in all subsequent EU CAP regulations. This clause provided the legal foundation for the 2015 EU decision to remove export subsidies. Multilateral pressure (i.e., the demands of third countries in GATT/WTO negotiations) is not the only determinant of CAP, but it is important, and its influence is affected by GATT/WTO having authority on agriculture.

Keywords: European Union, Common Agricultural Policy, GATT, World Trade Organization, international institutions, second image reverse, authority transfer.

\section{Introduction}

There is a debate in international relations on how, when, and why international institutions influence domestic policy. This paper focuses predominantly on the 'when'. More specifically, it looks at whether international institutions' influence on domestic policy increases when there is transfer of authority. This question emerges from two strands of literature: the second image reverse (SIR) research, and research on the politicization of international authority. Inverting the directional logic of the images of Waltz, Gourevitch (1978) introduced the idea that the international system (third image) 
also affected the structure of states (second image): the second image reverse. According to this literature, the capacity of international institutions to alter domestic policy depends on their strength, because 'international institutions embodied in toothless, non-binding agreements should have less influence ... than fully-fledged international institutions including binding treaties and regular meetings of multilateral fora' (Costa and Jørgensen 2012, 6). The strength of international institutions is also not static. While analysing the nexus between politicization and international authority, Zürn, Binder and Ecker-Ehrhardt $(2012,83)$ remind us that international institutions' strength is related to authority transfer (with the granting of competence to make certain decisions and judgements). The hypothesis that emerges is that a transfer of authority to an international organization increases its capacity to influence domestic policies.

We assess this hypothesis using the European Union (EU) (rather than the Member States) as the 'second image'. That is, the EU is the 'domestic' entity, with an internal single market. The EU was a contracting party to the updated General Agreement on Tariffs and Trade (GATT), and is a full member of the World Trade Organization (WTO). Moreover, agricultural policy is a common, internal, EU policy, and the EU is a political subject that engages internationally on agricultural products, where there is reason to believe it is influenced by international institutions (Costa and Jørgensen, 2012, 2). In treating the EU as the 'domestic' entity on which influence is exerted, yet where this influence also flows to the Member States through the EU's common policy, we are in effect creating a 'reverse second image plus'. Thus, this article looks at the influence of an international institution (the WTO) on another international institution (the EU) which in turn influences European member states' domestic policies through the Common Agricultural Policy (CAP). 
The first specific transfer of authority on agriculture from the EU to another international institution took place in 1994. Agricultural products were included in GATT in 1947, but a few years later the United States (US) obtained a waiver of unlimited duration to protect its agricultural policy, thus allowing the then European Economic Community and other GATT members to also establish protectionist agricultural policies. While the US shifted towards a pro-liberalization position on agriculture in the 1960s, the Europeans, among others, resisted (Josling and Tangermann, 1996). As a result, agricultural liberalization was piecemeal, with agreements only on a few products, which were also subject to many formal GATT disputes (for details see Swinbank, 2016). After several years of difficult negotiations, the first agreement on agriculture was reached during the Uruguay Round of negotiations of the GATT (1986-1994). The agreement introduced specific limits on both domestic support and export subsidies, as well as increased market access; in other words, specific rules for the liberalization of trade in agricultural products. This meant that the newly minted WTO had expanded authority over agriculture (Daugbjerg, Farsund and Langhelle, 2017, 1704). Accompanying this transfer of authority was the replacement of the diplomacy-based Dispute Settlement Mechanism of the GATT with the quasi-judicial arm of the WTO. ${ }^{1}$ Despite the initiation of a new Round of multilateral negotiations in 2001, the so-called WTO Doha Development Round (DDR), the Uruguay Round Agreement remained the only multilateral agreement on agriculture up until December 2015. At the WTO Ministerial hold in Nairobi in 2015, the WTO members reached agreement on a number of issues including the phasing out of export subsidies to agricultural products. 
To assess the hypothesis that authority transfer to an international organization (the GATT/WTO) increases its influence over domestic policies (here: the EU and its CAP), we look at the role played by multilateral pressure (i.e., the demands from third countries in GATT/WTO negotiations) on different CAP reforms. This is done through a review of both CAP legislation and the extensive literature on determinants of CAP reform. The analysis of CAP legislation shows that the influence of the Uruguay Round Agreement on Agriculture has been permanent. We show that this particular transfer of authority led to the introduction of a clause on export subsidies in a 1994 CAP regulation (Council of the EU, 1994, Art. 13), a clause that became a permanent feature of all subsequent CAP legislation. This clause, which allowed the EU to remove export subsidies without further legal or legislative ado, remained dormant for decades, until it facilitated the decision to remove export subsidies in the 2015 Nairobi WTO Ministerial Conference. While we do not assess the degree of influence from multilateral pressure vis-à-vis domestic EU factors in affecting the CAP, our review of the existing literature on CAP determinants shows that multilateral pressure was not considered an influencing factor prior to negotiations on authority transfer in the Uruguay Round. While multilateral pressure is one of several determinants, and its influence varies across time, the transfer of authority on agriculture to GATT/WTO in 1994 increased its capacity to influence the CAP. These insights both qualify the existing research on the impact of multilateral pressure on CAP reforms and lend credence to our hypothesis.

We divide the rest of this article into four sections. First, we provide a brief overview of the evolution of the CAP, identifying the different reforms that have taken place since its inception. ${ }^{2}$ Next, we review CAP legislation showing that the influence of the 1994 transfer of authority to GATT/WTO on agriculture has been permanent. 
Section three presents our review of the literature on the factors said to have determined CAP reforms, identifying their impact. The last section concludes.

\section{Common Agricultural Policy Reforms}

Although the objectives of the CAP remain those set out in Article 39 of the Treaty of Rome, the policy itself has greatly changed since the 1960s. There is consensus in the literature (cited in table 3) that the transformation has occurred through six CAP reforms that have changed the number of instruments of the policy and/or modified the existing instruments (see table 1); it has not been the result of a one-off revision. Since each of these reforms changed the substance of the policy they have to be considered in our analysis of the role played by multilateral pressure, thus the objective of this section is to identify and briefly present each of them.

(Table 1 here)

Today the CAP consists of two pillars. One is fully funded through the EU budget, providing for market support and direct payments to farmers based on decoupling (payments to farmers not based on type of product or on quantity produced), cross-compliance (need to comply with environmental, animal health and food safety standards), and restricted border protection (limits to tariffs and quotas); Member States co-finance the other pillar, which is for rural development. This is quite a different CAP than the one established in the 1960s. Despite some modifications of existing instruments in the 1980s, the CAP was, until 1992, a commodity support policy based 
on target prices, generous border protection and export subsidies, all financed by the Community budget. The policy at this time also included a limited set of structural measures (for rural development) co-financed by the Member States.

In 1992 the so-called MacSharry reform (named after the European Commissioner in charge of DG Agriculture at the time) introduced a new policy instrument and started the progressive removal of another; it began shifting assistance directly to producers (through income support and direct payments), replacing indirect support (tied to product prices and production). The new 1992 CAP regulations also introduced new measures on rural development (an agri-environmental programme, new subsidies for afforestation of agricultural land, and an early retirement scheme for farmers). Lastly, limits to border protection and to export subsidies were included in December 1994 to comply with the Uruguay Round Agreement on Agriculture. We include the review of CAP regulations that took place in December 1994 within the MacSharry reform, because the literature on the CAP's evolution (table 3) views these as part of the 1992 reform. The 1992 reform is widely considered to have included all the policy changes necessary to reach a multilateral agreement on agriculture at the Uruguay Round. The December 1994 regulation added the limits to tariffs, quotas, and export subsidies resulting from the final Agreement on Agriculture (Council of the EU, 1994).

The following reform, in 1999, continued this shift; one finalized in 2003. A reduction of target prices accompanied a continued shift from indirect to direct payments. Farmers were now obliged to respect specified environmental, animal health and food safety standards (optional cross-compliance) to receive full payment of their 
direct aid. The rural development arm of the CAP became the second pillar, and there was now a voluntary modulation (reduction of direct payments and transfer of money from the first pillar to the second pillar). The so-called Fischler reform (again, the name of the Commissioner in charge of CAP at the time) in 2003 made modulation compulsory and introduced another new instrument: decoupled direct payments. By so doing, it partially transformed support into a single flat-rate farm payment tied to compliance with environmental, animal health and welfare, and food safety regulations (compulsory cross-compliance) rather than with production requirements. For the new Member States (part of the 2004 enlargement) a simplified version of the single farm payment was introduced (starting at $25 \%$ of the EU15 rate in 2004) to progressively reduce the different treatment of 'older' and 'newer' members.

While leaving unchanged the number of policy instruments, the 2008 reform assigned a greater emphasis on land-use and sustainability, solidified in a 2013 revision (the latest reform of the CAP), and resulting in a 'greening' of payments. While direct payments are still tied to land, land must be kept in good agricultural condition (crosscompliance) and recipients must be farmers. Funds for rural development can be used to address new challenges, such as climate change, renewable energies, water management and biodiversity, at the discretion of each Member State. By 2019, the Single Payment Scheme will introduce an EU wide flat area payment that implies a new distribution of payments among member states and among farmers.

To sum up, the CAP has evolved from a commodity support policy based on target prices and strong protection against third country products, to a system of support with less competition-distorting support systems. One of the latest EU decisions on 
CAP is consistent with this evolution. ${ }^{3}$ In December 2015, the EU decided to remove, by January 2016, one of its oldest instruments of market support, namely its export subsidies for agricultural products.

\section{The Word Trade Organization's Permanent Influence}

This section shows that the legal foundation for the EU 2015 decision to remove export subsidies was introduced in 1994. The transfer of authority in agriculture to the GATT led to the introduction of a clause regarding export subsidies, which was included in all subsequent CAP regulations, including the 2013 reform. This clause laid dormant until it provided the legal foundation for the 2015 EU decision. Following the 1994 international Agreement on Agriculture, the WTO has thus been a permanent influence on the EU CAP, at least regarding export subsidies. The transfer of authority led not only to the introduction of new constraints (such as limits to export subsidies) on CAP but also the inclusion of new legal language in EU regulations; language that would facilitate further changes. This insight helps clarify the real impact of multilateral pressure on the 2013 reform and evidences that our hypothesis (that a transfer of authority to an international institution leads to greater capacity of influence in domestic policy) cannot be rejected.

The Agreement on Agriculture reached at the Uruguay Round laid the foundations of trade liberalization for agricultural products. All parties to the agreement knew it was the beginning of a process where they would be expected to continue lowering tariffs, domestic subsidies and export subsidies through future agreements. Article 20 of the Agreement provided for the start of new negotiations in the year 2000, 
'Recognizing that the long-term objective of substantial progressive reductions in support and protection resulting in fundamental reform is an ongoing process, Members agree that negotiations for continuing the process will be initiated one year before the end of the implementation period,...'

In the case of export subsidies, the EU introduced a legal provision that allowed for their reduction or removal through new multilateral agreements. To be more specific, since December 1994, all CAP regulations have included a clause that subordinates EU export subsidies to the limits resulting from international agreements concluded in accordance with Article 228 (later Article 300) of the Treaty of the European Union (cf. table 2).

(Table 2 here)

Our analysis of CAP legislation therefore indicates that the EU decided, concomitant with the conclusion of Uruguay Round Agreement, to leave the door open to removing export subsidies without further legal changes in case an international agreement was reached after the transfer of authority to the WTO. When the negotiations foreseen by Article 20 materialized in the Doha Agenda of 2001, one of the commitments of the parties was to evetually phase out all forms of export subsidies to agricultural products (WTO Ministerial, 2001, point 13). While reaching a preliminary agreement at the WTO Ministerial of Hong Kong in 2005, a final agreement was sealed in December 2015, and in the EU case, made possible by the provision included in CAP regulations since December 1994. 
At the WTO's Ministerial in Nairobi in December 2015, the EU agreed to remove export subsidies from its market support instruments beginning in January 2016 (with certain temporary exceptions for 1.35 million tons of sugar in 2017 and some support for dairy and pork until 2020). While previous CAP reforms, and the narrowing of global and EU market prices, had largely removed the need for export subsidies by $2012,{ }^{4}$ the removal of such an instrument would require a new revision of the CAP legislation and thus lengthy, and fraught, internal EU legislative wrangling. That is, unless existing legal provisions allowed for such a compromise.

The 2013 reform did not include a phasing out of export subsidies despite some debate on the matter. As mentioned above, the WTO Ministerial Conference in Hong Kong in 2005 had reached a preliminary agreement to that effect:

We agree to ensure the parallel elimination of all forms of export subsidies and disciplines on all export measures with equivalent effect to be completed by the end of 2013 . This will be achieved in a progressive and parallel manner, to be specified in the modalities, so that a substantial part is realised by the end of the first half of the implementation period (WTO Conference, 2005).

There was some internal EU debate on how to address this commitment. While the European Commission proposal for the 2013 CAP reform excluded the removal of export subsidies (see e.g. Mathews, 2012), the European Parliament development committee favoured their elimination (European Parliament, 2011). However, both the Council and the plenary of the European Parliament supported the Commission view that such a commitment was subject to an agreement in the WTO DDR negotiations. 
Since such agreement was lacking, the CAP 2013 revisions did not address export subsidies.

In other words, the removal of export subsidies agreed in Nairobi in 2015 was made possible by the provision included in CAP regulations since December 1994, and which laid dormant until 2015. Absent this clause, the EU would have had to open a new legislative process to allow for such a decision. Even if the diminished differences between global and EU market prices had largely removed the need for export subsidies, the EU could not have agreed to the compromise to remove export subsidies absent the existing clause subordinating EU export subsidies to the limits resulting from an international agreement. The clause had been present since 1994, and could have facilitated the impact of multilateral pressure on CAP substance at any time. However, since the multilateral agreement to remove export subsidies was reached in 2015 , our insight qualifies existing research on determinants of the 2013 CAP reform.

The 2013 reform was, according to the dominant literature (see next section), the first since the 1980s where multilateral pressure appeared irrelevant. Both Swinbank (2015) and Daugbjerg (2017) find that at the time the EU was not expecting an agreement on agriculture in the WTO DDR negotiations, and the 2013 reform did not introduce any change that could be interpreted as facilitating a multilateral agreement. According to these authors, the absence of multilateral pressure allowed for a partial reversal of the CAP's content. Specifically, production-related payments (practically eliminated in the 2008 revision) up to a maximum of $15 \%$ of the amount each state receives in the form of 'Single Payments' to farmers were reintroduced. Thus, 'The direction towards a gradual increase in the WTO compatibility of the CAP achieved in 
the period 1992/2008 stalled and domestic concerns took priority (primarily redistribution of support and the environment), resulting in some backtracking' (Daugbjerg 2017, 498). ${ }^{5}$ What our research indicates is that while CAP 2013 did not introduce any change to facilitate an agreement in the DDR negotiations, it preserved the dormant clause that facilitated the multilateral agreement reached in the December 2015 WTO Ministerial of Nairobi. By removing export subsidies in 2016, the EU changed the substance of the 2013 reform, resulting in a transformation of the CAP due to multilateral pressure.

\section{Multilateral Pressure}

If our analysis of CAP legislation shows that the influence of the Uruguay Round Agreement on Agriculture has been permanent, the review of the existing literature on CAP reform determinants shows that multilateral pressure only became a factor during the negotiations leading to that transfer of authority. While multilateral pressure has never been the only determinant of CAP reforms, and its impact (type of influence) does not follow a set pattern, the 1994 transfer of authority on agriculture to GATT/WTO increased its capacity to influence CAP.

Studies looking at a specific reform, as well as those taking a comparative approach, have tried to pinpoint the determinants of CAP reforms (see table 3). In this section, we summarize and tabulate the extensive literature on this topic, presenting the scholarly assessments of whether one or more of the main CAP determinants influenced the timing (when reforms were initiated), substance (CAP instruments), funding (the amount of financial support for the CAP), and equity (redistribution of financial support 
to farmers) of a particular reform. We assume that if the literature has identified a determinant as having an impact on a qualitative variable the absence of such a factor would result in a different reform. While there is no consensus among policy makers or researchers on all the internal factors, nor which has the greatest impact (Daugbjerg and Swinbank 2009; Cunha and Swinbank 2009), the literature reveals five dominant internal influences (the EU budget, EU enlargement, previous CAP reforms, the European institutional setting and paradigm shifts) and one external (multilateral pressure). The objective of this review is to assess when multilateral pressure exerted an influence on the CAP, with or without the EU domestic factors, rather than the degree of influence of each. We look at which factors were identified as having influenced each of the six CAP reforms and at their type of influence.

(Table 3 here)

Both quantitative and qualitative studies on the importance of multilateral pressure on CAP reforms have looked at how changes enabled the CAP to comply with third country demands. There is widespread agreement among both academics and practitioners that with the exception of the 1980s and 2013, rounds of multilateral trade negotiations (an external determinant) influenced policy changes. ${ }^{6}$ Daugbjerg and Swinbank $(2007 ; 2009)$ find multilateral negotiations important in explaining the timing and substance of CAP reforms in the early 1990s and the early 2000s. Regarding equity, Henning and Latacz-Lohmann (2004, 41-42) argued - prior to the 2004 enlargement that there was gridlock in the Council of Ministers of Agriculture due to differing preferences on multifunctionality, and extreme positions on levels of support, resulting in a stalemate (status-quo). However, they find that external shocks, such as further 
pressure from further WTO restrictions, served to mitigate extreme positions, break up the gridlock, and make the CAP more efficient, effective and equitable. The implication is that multilateral pressure is a force capable of changing the CAP's policy instruments and by so doing affect the redistribution of financial support among EU farmers (equity).

However, even researchers who previously, and continuously, emphasised multilateral pressure deemed it irrelevant for the 2013 revision (Swinbank 2015; Daugbjerg 2017). The reason, they argue, is that the revision did not introduce any changes that facilitated, or could be interpreted as facilitating, a multilateral agreement in the WTO DDR negotiations. As we have evidenced in the previous section, their conclusion should be qualified by taking into account the multilateral agreement on export subsidies reached at the WTO Ministerial of December 2015. The EU decision to accept to remove exports subsidies was facilitated by a dormant clause included in the 2013 CAP legislation. We therefore consider that multilateral pressure influenced the substance of the CAP 2013 revision.

Our review of the literature indicates that internal determinants of CAP reforms can be divided into two groups, based on their type of influence. The first group consists of previous CAP reforms, the European institutional setting and paradigm shifts, and these determinants mostly affect substance and equity, while the budget and enlargement primarily influence funding, thus representing a second group.

Path dependency is a key element of historical institutionalism, and suggests that 'present structure, or functioning, can only be understood when embedded in a historical 
perspective' (Daugbjerg 2009, 395). Using this theory - emphasizing a self-reinforcing continuation of policy or developments through a reactive sequence - scholars show that every CAP reform builds on or is a reaction to, a previous one (Kay, 2003; Garzon 2006; Daugbjerg, 2009; Grant, 2010). Gradual policy layering may also explain why the CAP largely remained intact in its 2013 reconfiguration despite the empowerment of those interests who wanted the CAP to return to a more traditional mode of support (Daugbjerg and Swinbank 2016). Recent research also points to the emergence of 'a new national path dependency re-shaping the CAP implementation' (Henke et al 2018, 403), which may open a new strand of research on path-dependency in the CAP.

Much of the literature exploring the impact of EU institutions on reforming the CAP concludes that the European Commission has often played a key role, although its latitude to bring about change is limited (Daugbjerg 2009, 399; Lynggaard and Nedergaard 2009, 294). Nevertheless, scholars have mostly examined institutions in order to understand how the EU's internal process leads to a CAP reform, rather than as a factor explaining why one took place (Garzon 2006). The focus has been on assessing how institutions promote, restrict, and otherwise influence decision-making on agricultural issues, including how the EU addresses and reconciles internal and external pressures. For example, Haniotis (2006) attributes different European and American responses to similar external pressure in the agricultural field to them having different institutions. $^{7}$

As to paradigm shifts or ideas, constructivist scholars argue that 'ideas informing the CAP have not remained the same and that expectations of what the CAP should deliver have changed in the course of its development' (Lynggaard and Nedergaard 
2009, 296). Furthermore, 'CAP's nature has fundamentally changed from a simple productivity focus to a comprehensive multi-layered policy' (Medina and Potter 2017, 384). The rationale informing the CAP has moved from a dependent (state-assisted) agriculture paradigm towards multifunctional and competitive (market liberal) agriculture paradigms through a 'cumulative paradigm change' (Daugbjerg and Swinbank 2011, 131). These studies have concentrated on pinpointing the evolution of the ideational structure prevailing at the time of each change to the CAP, in order to explain the underlying forces of political processes, often focusing on discursive developments (Potter and Tilzey 2007; Ackrill, Kay, and Morgan 2008; Lynggaard and Nedergaard 2009; Grant 2010). Focusing on the 2013 CAP revision, one study also finds that 'at a single point in time, agricultural policies can be in line with several paradigms to various degrees' while pointing out that discourses are prone to strategic usage (Alons and Zswaan 2015, 350). In sum, researchers recognise that the constructivist determinant is not a trigger for reform, but rather a constraint on the direction of the substance and equity.

Regarding the second group of internal determinants that emerges from our analysis, both the budget and enlargement influence funding, and, specially in the case of the budget, timing. When assessing financial influence on CAP reforms scholars have looked for evidence of budgetary constraints, and then logically deduced that these restrictions affected the CAP. It is probably the first explanatory factor for a CAP reform identified by the literature: 'Until the late 1980s there was little doubt among CAP analysts that budgetary concern was the major driving force capable of generating CAP reform.' (Daugbjerg and Swinbank 2011, 127). It has remained an explanatory factor for all CAP reforms because funding is affected by budgetary ceilings (Kay 2003; 
Ackrill, Kay, and Harvey 2006; Daugbjerg and Swinbank 2011) and because 'the desire to avoid major budgetary redistribution among member states is an important constraint in the evolution of the CAP' (Daugbjerg 2009, 397). Thus, there is consensus that the budget has had a direct influence on the funding available in CAP reforms. Since each reform of the EU budget has prompted a negotiation on the CAP, the budget has also been a determinant of timing in almost all CAP reforms. However, as the 2003 reform shows, changes in CAP instruments may happen even without impending budget negotiations.

As to enlargement pressure, research has focused on assessing the impact of enlargement on structural changes in the agricultural sector, specifically on whether enlargement fosters, or makes more difficult, CAP changes. Jensen et al (2009) show that EU enlargements have, for the most part, led to the expansion of EU agricultural production, and that the higher the agricultural production in a member state the less willing they are to reform the CAP. Henning and Latacz-Lohmann $(2004,42)$ find that the 2004 enlargement made the Council more heterogeneous in terms of the political interests represented, but also more supportive of higher levels of agricultural support. Thus 'enlargement, at most, poses a further obstacle to reform'. However, others find that enlargement may promote CAP reform. Henning $(2008,41)$ contends that 'enlargement might be a driver of CAP reforms ex ante the EU's expansion, while it is an obstacle to future reforms ex post ${ }^{8}{ }^{8}$ This literature indicates that while enlargement had an impact on the timing of reforms in 1999, its impact was on substance in 2003 and 2008. Moreover, enlargement has been seen as furthering the budgetary constraint (Cunha 2004, 155). Since the growth of the CAP's budget has been limited since the 1980s due to different stability mechanisms, enlargement is a constraint on the funding 
for CAP. Furthermore, enlargement is considered irrelevant to the 2013 CAP reform because the latter addresses the equity problems previous enlargement agreements created, rather than dealing with enlargement per se.

\section{(Table 4 here)}

Our literature review of the influences on timing, substance, funding, and equity (table 4) lends further credence to our hypothesis. It reveals that multilateral pressure was not a determinant of reform prior to negotiations on the 1994 transfer of authority. It became a determinant with the 1992 reform, which is considered to include not only the regulatory changes of 1992 but also those introduced in December 1994. Therefore, the transfer of authority to the GATT/WTO increased the potential for multilateral pressure to influence the CAP. The increase in multilateral pressure capacity of influence after the authority transfer should however not be overestimated. While we do not assess the degree of influence of multilateral pressure vis-à-vis domestic EU factors in affecting the CAP, the literature review shows that this factor was one among several. After the authority transfer to WTO in agriculture, multilateral pressure did not become the only determinant of any specific aspect of CAP reform; most internal factors help explain some part of every CAP reform. In fact, only in 2003 did multilateral pressure influence an aspect of CAP reform (timing) that the other determinants did not. In all the other cases, other determinants have also influenced the same aspects of reforms to the CAP as multilateral pressure. Our literature review also indicates that the influence of multilateral pressure after the transfer does not follow a clear pattern. It has influenced the substance and equity in all reforms since the early 1990s, yet in 2013 it 
just influenced substance, and it had an added impact on timing on only two occasions (1992 and 2003).

\section{Conclusion}

Multilateral pressure has influenced the EU agricultural sector. The CAP has evolved toward market-oriented policies, with less competition-distorting support systems. This article has shown that while multilateral pressure is only one of several factors explaining CAP reforms, and its effect does not follow a set pattern, its influence increased concomintant with the negotiations on the 1994 transfer of authority on agriculture to GATT/WTO. At least on export subsidies, 21st century CAPs were designed to allow for and adapt to new multilateral agreements.

While the last CAP reform in 2013 did not introduce any change that appeared to facilitate an agreement in the DDR negotiations, the EU's Nairobi decision to accept the removal of export subsidies to agricultural products indicates that the reform did allow for change. 2013 CAP regulations included a clause, long dormant, that allowed for such a decision, and we showed that this clause on export subsidies had been in place since 1994. Following the 1994 international Agreement on Agriculture, all reforms of the CAP were designed to take into account the multilateral level, at least regarding export subsidies. In short, we show that multilateral pressure has had an impact on all CAP reforms since 1992. This finding qualifies the literature regarding multilateral pressure on the 2013 CAP reform. Furthermore, from an international relations viewpoint, this study evidences that the transfer of authority to international institutions, here from one institution (the EU) to another (GATT/WTO), where the former is taken 
as the 'domestic' setting, may transform an external factor into a permanent influence on domestic policy.

\section{References}

Ackrill, R., A. Kay, and D. Harvey. 2006. "The EU Budget and the CAP: An Agenda for the Review?" Eurochoices, 5 (3): 20-25.

Ackrill, R., A. Kay and W. Morgan. 2008. "The common agricultural policy and its reform: the problem of reconciling budget and trade concerns." Canadian journal of agricultural economics 56 (4): 395-411.

Alons, G. and P. Zswaan. 2015. "New wine in different bottles: Negotiating and selling the CAP post-2013 reform.” Sociologica Ruralis 56 (3): 349-370.

Burrell, A. .2009. “The CAP: looking back, looking ahead.” Journal of European Integration 31 (3): 271-289.

Coleman, W.D. and S. Tangermann. 1999. "The 1992 CAP Reform, the Uruguay Round and the Commission.” Journal of Common Market Studies 37(3): 385-405. Cunha, A. 2004. "A role of direct payments? The Doha round, EU enlargement and prospects for CAP reform." in A bond scheme for common agricultural reform. Edited by Swinbank, A. and Tranter, R., 149-173. Wallingford: CABI publishing.

Cunha, A. and A. Swinbank 2011. An Inside View of the CAP Reform Process: Explaining the MacSharry, Agenda 2000 and Fischler Reforms. Oxford: Oxford University Press.

Costa, O. and E. Jørgensen .2012. "The Influence of International Institutions on the EU: A Framework for Analysis." In The Influence of International Institutions on the EU. Edited by Costa, O. and Jørgensen, E., 1-14. Basingstoke: Palgrave Macmillan. 
Council of the European Union (1994) Council Regulation (EC) No. 3290/94 of 22

December 1994 on the adjustments and transitional arrangements required in the agriculture sector in order to implement the agreements concluded during the Uruguay Round of multilateral trade negotiations.

Daugbjerg, C. 2009. "Sequencing in public policy: the evelution of the CAP over a decade." Journal of European PublicPpolicy 16 (3): 395-411.

Daugbjerg, C. 2017. "Responding to non-linear internationalization of public policy: The World Trade Organization and reform of the CAP 1992-2013." Journal of Common Market Studies 55 (3): 486-501.

Daugbjerg, C., A.A. Farsund and O. Langhelle. 2017. "The resilience of paradigm mixes: food security in a post-exceptionalist trade regime" Journal of European Public Policy 24(11), 1698-1715.

Daugbjerg, C. and A. Swinbank .2007. "The politics of CAP reform: trade negotiations, institutional settings and blame avoidance.” Journal of Common Market Studies 45 (1): $1-22$.

Daugbjerg, C. and A. Swinbank. 2009. Ideas, institutions, and trade: the WTO and the curious role of EU farm policy in trade liberalization. Oxford: Oxford University Press. Daugbjerg, C. and A. Swinbank. 2011. "Explaining the "health check" of the common agricultural policy: budgetary politics, globalization and paradigm change revisited." Policy Studies 32 (2):127-141.

Daugbjerg, C. and A. Swinbank. 2016. “Three Decades of Policy Layering and Politically Sustainable Reform in the European Union's Agricultural Policy." Governance: an International Journal of Policy, Administration and Institutions 29 (2): $265-280$. 
European Commission. 2010. "The CAP towards 2020: Meeting the Food, Natural Resources and Territorial Challenges of the Future." COM(2010) 672 final. Brussels: CEC.

European Parliament. 2011. Opinion 2011/0281(COD). Development committee. European Council. 1994. (EC) Regulation No 3290/94 of 22 December 1994 on the adjustments and transitional arrangements required in the agriculture sector in order to implement the agreements concluded during the Uruguay Round of multilateral trade negotiations. OJ L 349, 31.12.1994, p. 105-200

Garzon, I. 2006. Reforming the Common Agricultural Policy: History of a Paradigm Change. Basingstoke: Palgrave Macmillan

Gourevitch, P. 1978. "The Second Image Reversed: The International Sources of Domestic Politics.” International Organization 32(4): 881-912.

Grant, W. 2010. "Policy instruments in the common agricultural policy." West European Politics 33 (1): 22-38.

Haniotis, T. 2006. “The 2003 reform of the European union's common agricultural policy and its relevance to the U.S. farm policy debate." In U.S. Agricultural Policy and the 2007 Farm Bill. Edited by Kaush, A., T. Josling, D. A. Summer, and B. H. Thompson, 53-74. Stanford University: Woods Institute for the Environment. Henke, R., T. Benos, F. De Filippis, M. Giua, F. Pierangeli and M.R. Pupo d'Andrea (2018) “The New Common Agricultural Policy: How do Member States Respond to Flexibility?"Journal of Common Market Studies 56(2): 403-419.

Henning, C. 2008. "EU enlargement: Driver of or obstacle to future CAP reforms?" In The Perfect Storm: the Political Economy of the Fischer Reforms of Common Agricultural Policy. Edited by Swinnen, J.F.M. 41-56. Brussels: Centre for European Studies. 
Henning, C. and U. Latacz-Lohmann. 2004. "Will Enlargement Gridlock CAP reforms? A Political Economy Perspective.” Eurochoices 3 (1): 41-42.

Jensen, M.S., K.M. Lind and H. Zobbe. 2009. "Enlargment of the European Union and agricultural policy reform." Journal of European Integration 31 (3): 329-348.

Josling, T. 2008. "External Influences on CAP Reforms: A Historical Perspective” In

The Perfect Storm: the Political Economy of the Fischer Reforms of Common

Agricultural Policy. Edited by Swinnen, J.F.M., 57-75. Brussels: Centre for European Studies.

Josling, T.E. and S. Tangermann. 1996. Agriculture in the GATT. Basingstoke:

Macmillan.

Kay, A. 2003. "Path dependency and the CAP." Journal of European Public Policy 10 (3): 405-420.

Lovec, M. and E. Erjavec. 2013. "The common agricultural policy health check: time to check the healthy of the theory of the reform?" Journal of Iinternational Relations and Development 16 (1): 111-137.

Lynggaard, K. and P. Nedergaard. 2009. “The logic of policy development: lessons learned from reform and routine within the CAP 1980-2003." Journal of European Integration, 31(3): 291-309.

Matthews, A. 2012. "End the use of export subsidies in the 2013 CAP review."

CAPReform.eu, April 2012. Available at www.capreform.eu/end-the-use-of-exportsubsidies-in-the-2013-cap-review/

Matthews, A. 2013. “The end of export subsidies.” CAPReform.eu. September 2013. Available at: capreform.eu/the-end-of-export-subsidies/.

Matthews, A. 2015. “The Multi-Annual Financial Framework and the 2013 CAP Reform." In The Political Economy of the 2014-2020 Common Agricultural Policy: an 
Imperfect Storm. Edited by Swinnen, J.F.M., 169-191. London: Rowman and Littlefield International.

Medina, G. and C. Potter (2017) "The nature and developments of the Common Agricultural Policy: lessons for European integration from the UK perspective.” Journal of European Integration, 39(4): 373-388.

Meunier, S. 2005. Trading Voices: The European Union in International Commercial Negotiations . Princeton, NJ: Princeton University Press.

Nedergaard, P. 2006. “The 2003 Reform of the Common Agricultural Policy: Against all Odds or Rational Explanations?” Journal of European Integration, 28 (3): 203-223. Potter, C. and M. Tilzey. 2007. “Agricultural multifunctionality, environmental sustainability and the WTO: Resistande or Accommodation to teh neoliberal project for agriculture?" Geoforum 38, 1290-1303.

Swinbank, A. 2015. “The WTO: no longer relevant for CAP reform?” In The Political Economy of the 2014-2020 Common Agricultural Policy: An Imperfect Storm. Edited by Swinnen, J., 193-213. London: Rowman and Littlefield International.

Swinbank, A. 2016. The Interaction between the EU's External Action and the Common Agricultural Policy. Research for Agri-Committee of the European Parliament. Available at:

http://www.europarl.europa.eu/thinktank/es/document.html?reference=IPOL_STU(2016 $\lcm{585879}$ (accessed 24 January 2018)

Swinbank, A. and Tanner, C. 1996. Farm Policy and Trade Conflict. The Uruguay Round and CAP Reform. Ann Arbor, MI: The University of Michigan Press Swinbank, A. and Tranter, R. 2004. A bond scheme for CAP reform. Oxfordshire: CABI Publishing. 
Swinnen, J.F.M. 2008. "The Political Economy of the Fischler Reforms of the EU's Common Agricultural Policy. The Perfect Storm?' In The Perfect Storm: the Political Economy of the Fischer Reforms of Common Agricultural Policy. Edited by Swinnen, J.F.M. 135-166. Brussels: Centre for European Studies.

World Trade Organization Ministerial Conference. 2001. Fourth session. Doha 9-14 November 2001, at https://docs.wto.org/dol2fe/Pages/FE_Search/FE_S_S009-

DP.aspx ?language $=\mathrm{E} \&$ CatalogueIdList $=37246 \&$ CurrentCatalogueIdIndex $=0 \&$ FullText Search $=($ accessed 3 June, 2018)

World Trade Organization Ministerial Conference. 2005. Sixth Session, Hong Kong, 13 - 18 December 2005, at https://docs.wto.org/dol2fe/Pages/FE_Search/FE_S_S009DP.aspx ?language $=E \&$ CatalogueIdList $=70196 \&$ CurrentCatalogueIdIndex $=0 \&$ FullText Search $=($ accessed 1 July 2017)

World Trade Organization Ministerial Conference. 2015. Tenth session, Nairobi, 15-18 December 2015, from European Commission News on the Doha Developement Agenda (12/14/2015) at http://trade.ec.europa.eu/doclib/events/index.cfm?id=1414 (accessed 5 July 2017)

Zürn, M., M. Binder and M. Ecker-Ehrhardt (2012) "International authority and its politicization" International Theory 4(1): 69-106.

Table 1. The six CAP reforms

\begin{tabular}{|l|l|}
\hline Reform & Type of substantive changes \\
\hline 1980 s & Modification of existing instruments \\
\hline 1992 & $\begin{array}{l}\text { Introduction of new instruments and } \\
\text { modification of existing ones }\end{array}$ \\
\hline 1999 & Modification of existing instruments \\
\hline
\end{tabular}




\begin{tabular}{|l|l|}
\hline 2003 & Introduction of new instruments and \\
& modification of existing ones \\
\hline 2008 & Modification of existing instruments \\
\hline 2013 & Modification of existing instruments \\
\hline
\end{tabular}

Source: Own elaboration on the grounds of the literature cited in table 3.

Table 2. CAP Regulations and Export subsidies dormant clause

\begin{tabular}{|c|c|c|}
\hline CAP Reforms & EU Regulations & $\begin{array}{l}\text { Export subsidies dormant } \\
\text { clause }\end{array}$ \\
\hline 1992 & $\begin{array}{l}\text { 1766/92 Cereals } \\
\text { 2066/92 Bovine meat } \\
\text { 2071/92 Milk }\end{array}$ & $\begin{array}{l}\text { None } \\
\text { None } \\
\text { None }\end{array}$ \\
\hline $\begin{array}{l}\text { Uruguay Round } \\
\text { implementation }\end{array}$ & $\begin{array}{l}\text { 3290/94 All products } \\
\text { Case Cereals (same } \\
\text { article/different number for } \\
\text { each product in Annex II) }\end{array}$ & $\begin{array}{l}\text { Art.13 ....on the basis of } \\
\text { quotations or prices for those } \\
\text { products on the world market } \\
\text { and within the limits } \\
\text { resulting from agreements } \\
\text { concluded in accordance } \\
\text { with Article } 228 \text { of the } \\
\text { Treaty, the difference } \\
\text { between those quotations or } \\
\text { prices and prices in the } \\
\text { Community may be covered } \\
\text { by export refunds. }\end{array}$ \\
\hline 1999 & $\begin{array}{l}\text { 1254/99 Bovine meat } \\
\text { 1493/99 Wine }\end{array}$ & $\begin{array}{l}\text { Art. } 33 \text { (1) idem } \\
\text { Art } 63 \text { (1) idem }\end{array}$ \\
\hline 2003 & $\begin{array}{l}\text { 1784/2003 Cereals } \\
\text { 1785/2003 Rice }\end{array}$ & $\begin{array}{l}\text { Art } 13 \text { (1) idem } \\
\text { Art. } 13 \text { (1) idem }\end{array}$ \\
\hline 2006 & $318 / 2006$ Sugar & Art. 32(1) idem \\
\hline 2008 & $1234 / 2007$ All products & Art. 162 (1) ídem \\
\hline 2013 & $1308 / 2013$ All products & Art.196(1) ídem \\
\hline
\end{tabular}

Source: Own elaboration

$\underline{\text { Table 3. Single and comparative studies of the determinants of CAP reforms }}$ 


\begin{tabular}{|c|c|c|}
\hline Determinants & Single reform studies & Comparative reforms studies \\
\hline $\begin{array}{l}\text { Multilateral } \\
\text { pressure }\end{array}$ & $\begin{array}{l}\text { Swinbank and Tanner } \\
\text { (1996): } 1992 \text { reform } \\
\text { Coleman and Tangermann } \\
\text { (1999): } 1992 \text { reform } \\
\text { Swinbank and Tranter } \\
\text { (2004): } 1992 \text { reform } \\
\text { Nedergaard (2006): } 2003 \\
\text { reform } \\
\text { Josling (2008): 2003 reform } \\
\text { Swinnen (2008): } 2003 \\
\text { reform } \\
\text { Daugbjerg and Swinbank } \\
\text { (2011): } 2008 \text { reform } \\
\text { Swinbank (2015): } 2013 \\
\text { reform }\end{array}$ & $\begin{array}{l}\text { Meunier (2005): reforms 1980s till } \\
2003 \\
\text { Garzon (2006): reforms 1980s till } \\
2003 \\
\text { Daugbjerg and Swinbank (2007): } \\
\text { 1992, } 1999 \text { and } 2003 \text { reforms } \\
\text { Ackrill et al (2008): reforms 1980s } \\
\text { till } 2003 \\
\text { Daugbjerg and Swinbank (2009): } \\
1992,1999 \text { and 2003 reforms } \\
\text { Cunha and Swinbank (2011): } 1992 \text {, } \\
1999 \text { and } 2003 \text { reforms } \\
\text { Daugbjerb (2017): reforms } 1992 \\
\text { until } 2013\end{array}$ \\
\hline Budget pressure & $\begin{array}{l}\text { Matthews (2015): } 2013 \\
\text { reform }\end{array}$ & $\begin{array}{l}\text { Ackrill et al (2008): reforms 1980s } \\
\text { till } 2003\end{array}$ \\
\hline Enlargement & $\begin{array}{l}\text { Henning and Latcz- } \\
\text { Lohmann (2004): } 2003 \\
\text { reform } \\
\text { Cunha (2004): } 2003 \text { reform }\end{array}$ & $\begin{array}{l}\text { Henning (2008): } 2003 \text { and } 2008 \\
\text { reforms } \\
\text { Jensen et al (2009): } 1992 \text { and } 2003 \\
\text { reforms } \\
\text { Lovec and Erjavec (2013): reforms }\end{array}$ \\
\hline
\end{tabular}




\begin{tabular}{|c|c|c|}
\hline & & since 2003 \\
\hline Path dependency & $\begin{array}{l}\text { Henke et al (2018): } 2013 \\
\text { reform }\end{array}$ & $\begin{array}{l}\text { Kay (2003): reforms up until } \\
2003 \\
\text { Daugbjerg (2009): CAP reforms } \\
\text { from 1990s to } 2008 \\
\text { Daugbjerg and Swinbank (2016): } \\
\text { reforms since the 1980s }\end{array}$ \\
\hline $\begin{array}{l}\text { Institutional } \\
\text { setting }\end{array}$ & $\begin{array}{l}\text { Haniotis (2006): } 2003 \\
\text { reform } \\
\text { Nedergaard (2006): } 2003 \\
\text { reform }\end{array}$ & $\begin{array}{l}\text { Daugbjerg and Swinbank (2007): } \\
1992,1999 \text { and } 2003 \text { reforms }\end{array}$ \\
\hline Ideas & $\begin{array}{l}\text { Alons and Zwaan (2015): } \\
2013 \text { reform }\end{array}$ & $\begin{array}{l}\text { Potter and Tilzey (2007): reforms } \\
\text { between } 1980 \text { and } 2003 \\
\text { Lynggaard and Nedergaard (2009): } \\
\text { reforms between } 1980 \text { and } 2003 \\
\text { Daugbjerg and Swinbank (2009): } \\
\text { 1992, } 1999 \text { and } 2003 \text { reforms } \\
\text { Medina and Potter (2017): all } \\
\text { reforms }\end{array}$ \\
\hline All & N/A & Garzon (2006): reforms till 2003 \\
\hline
\end{tabular}


Table 4. Determinants' impact on timing, substance, funding and equity (drawn from the literature review and results from section 3).

\begin{tabular}{|l|c|c|c|c|c|c|}
\hline pressure & $\mathbf{1 9 8 0 s}$ & $\mathbf{1 9 9 2}$ & $\mathbf{1 9 9 9}$ & $\mathbf{2 0 0 3}$ & $\mathbf{2 0 0 8}$ & $\mathbf{2 0 1 3}$ \\
\hline Multilateral & not & timing, & Substance, & timing, & Substance, & Substance \\
& & substance, & equity & substance, & equity & \\
\hline Budget & timing, & timing, & timing, & Funding, & timing, & timing, \\
& substance, & funding & funding & & funding & funding \\
\hline Enlargement & Funding & funding & timing, & substance, & substance, & not \\
& & & funding & funding & funding & relevant \\
\hline Previous & substance, & substance, & substance, & substance, & substance, & substance, \\
CAP & equity & equity & equity & equity & equity & equity \\
reforms & substance, & substance, & substance, & substance, & substance, & Substance, \\
\hline Institutional & substance, & substance, & substance, & substance, & substance, & substance, \\
& equity & equity & equity & equity & equity & equity \\
\hline
\end{tabular}

Source: Own elaboration on the ground of table 2 bibliography and results from section 3.

\footnotetext{
${ }^{1}$ Under the new Dispute Settlement Mechanism non-compliance with WTO agreements leads to retaliation from other membres. There is literature on how the EU sugar regime (for exemple) has changed to comply with decisions from the WTO judicial arm (see Swinbank, 2016).

${ }^{2}$ Since the focus here is on multilateral pressure, we do not distinguish between reforms (adding or removing instruments in the CAP) and revisions (modifications to instruments).
} 
${ }^{3}$ There were some new developments regarding the CAP in late 2017. The mid-term review of the EU's financial perspectives led to technical changes in the CAP 2013 regulations through the Omnibus Agricultural Provisions Regulation (EU) 2017/2393. ${ }^{4}$ See for exemple Matthews, 2013. Following the EU notifications on export subsidies to the WTO, the EU totally stopped using this instrument in 2014/15 (G/AG/N/EU/29). In 2012/13 export subsidies were just used for one product (G/AG/N/EU/22) and in 2013/14 they were almost non-existent (G/AG/N/EU/25).

${ }^{5}$ Daugbjerg and Swinbank $(2016,276)$ recognise, however, that the policy reversal in 2013 was very limited since the stalemate in the DDR (since 2008) could potentially have allowed a reversal of the CAP back to its 1992 version (which already allowed the CAP to comply with the Uruguay Round's Agreement on Agriculture).

${ }^{6}$ Accepting that multilateral pressure plays a role in explaining CAP revisions does not mean considering that this role is predominant. Jean-Christophe Bureau claims on CAPReform.eu ('Does the WTO discipline really constrain the design of CAP payments?', October 23, 2017) that: "In the past, the WTO constraint has often been used by Member States as well as the Commission to justify policies that were largely self-imposed. ... In reality, all major CAP reforms were driven much more by domestic constraints than the WTO. ...".

${ }^{7}$ It is interesting to note that analysts agree that farm organisations have become less powerful in the process. Grant (2010, p 36) argues that the terrain 'has been occupied by environmental, third world and consumer organizations'.

${ }^{8}$ Lovec and Erjavec (2013) nonetheless recently find that enlargements may have an expost impact on CAP reforms. In particular, they argue that the 2004 enlargement - by shifting the geographical distribution of production (primarily eastward) - explains the increased flexibility of payment schemes. 